Artigo Original

\title{
Titanium dioxide immobilization in recycled aluminum net for degradation of tex- tile dye by Heterogeneous Photocatalysis through neural networks
}

\author{
Imobilização de dióxido de titânio em malha de alumínio reciclado para a degradação de \\ corante têxtil por Fotocatálise Heterogênea por Redes Neurais \\ Ingrid Larissa da Silva Santana'; Ada Azevedo Barbosal"; Marina Gomes Silva'll; \\ Ramon Vinícius Santos de Aquino'v; Naiana Santos da Cruz Santana Neves"; \\ Josivan Pedro da Silva ${ }^{\mathrm{VI}}$; Isis Henriqueta dos Reis FerreiraVII; Otidene Rossiter Sá da RochaVIII
}

\section{Abstract}

In this work, recycled aluminum nets were used as $\mathrm{TiO}_{2}$ support for the treatment of the textile dye Remazol golden yellow (RGY 150). The immobilization of $100 \mathrm{mg}$ of $\mathrm{TiO}_{2}$ was accomplished after aluminum net calcination. The following experiments were carried out in a photocatalytic bench reactor: preliminary tests, a $2^{3}$ factorial experimental design with the best system and the degradation kinetic of $\mathrm{TiO}_{2}$ supported systems. Characteristic peaks of aluminum and $\mathrm{TiO}_{2}($ anatase and rutile) were observed by XRD and the catalyst film formation was verified by SEM. The system $\mathrm{UV} / \mathrm{H}_{2} \mathrm{O}_{2} / \mathrm{TiO}{ }_{2}$ performed higher efficiency, with $99 \%$ of dye degradation in 50 minutes, followed by the system $\mathrm{UV} / \mathrm{H}_{2} \mathrm{O}_{2} / \mathrm{TiO}_{2 \mathrm{sp}}$ with $93 \%$ of dye degradation. Whereas the supported catalyst presents execution advantages and high degradation rates, the factorial design was realized for this system, achieving best degradation (100\% degradation in 35 minutes). It was obtained $\mathrm{k}=0.114$ min ${ }^{-1}$ and $\mathrm{R}^{2}=0.994$ in a pseudo-first order model adjustment. The use of artificial neural network was proven to be efficient to predict the degradation of a textile dye with an absolute error of 0.0181 . After treatment, there was a decrease of dye toxicity.

Keywords: Aluminum net. Advanced Oxidation Process. Remazol golden yellow. Photocatalysis. Phytotoxicity.

\section{Resumo}

Neste trabalho, redes de alumínio recicladas foram utilizadas como suporte de TiO2 para o tratamento do corante têxtil Remazol amarelo ouro (RGY 150). A imobilização de 100 mg de TiO2 foi realizada após calcinação do material de alumínio. Foram conduzidos em reator de bancada fotocatalítico testes preliminares, um experimento fatorial $2^{3}$ com o melhor sistema e a cinética de degradação em sistemas com $\mathrm{TiO}_{2}$ suportado em rede de alumínio. Foram observados picos característicos de alumínio e $\mathrm{TiO}_{2}$ (anatase e rutilo) por DRX e a formação do filme catalítico foi verificada por MEV. O sistema UV/ $/ \mathrm{H}_{2} \mathrm{O}_{2} / \mathrm{TiO}_{2}$ apresentou maior eficiência, com $99 \%$ de degradação do corante em 50 minutos, seguido do sistema $\mathrm{UV} / \mathrm{H}_{2} \mathrm{O}_{2} / \mathrm{TiO} 2$ sp com $93 \%$ de degradação do corante. Enquanto o catalisador suportado apresenta vantagens de execução e altas taxas de degradação, o planejamento fatorial foi realizado para este sistema, apresentando melhor degradação (100\% de degradação em 35 minutos). Foi obtido $\mathrm{k}=0,114 \mathrm{~min}^{-1}$ e $\mathrm{R}^{2}=0,994$ em um sistema de ajuste de modelos de pseudo-primeira ordem. O uso da rede neural artificial mostrou-se eficiente para predizer a degradação de um corante têxtil, com erro absoluto de 0,0181. Após o tratamento, houve uma diminuição da toxicidade do corante.

Palavras-chave: Malhas de alumínio. Processos Oxidativos Avançados. Remazol amarelo ouro. Fotocatálise. Fitotoxicidade. 


\section{Introduction}

The textile industry is one of the major producer of waste water containing dyes and chemical products (ASGHAR; RAMAN; DAUD, 2015; HASSAAN; NEMR, 2017). The environmental impact by the textile sector provides a representative pollutant potential, once the industrial wastes are very diverse and their chemical composition vary according to the industry typology and the involved processes. This effluent class is considered toxic and contains non-biodegradable compounds and the dyes derived from industrial processes are largely responsible for this characteristic (ALISANFI et al., 2007). Therefore, it is necessary to develop alternative methods for waste treatment that ensure a contaminant level decrease after treatment.

Moreover, through these processes, the organic molecules complete or partial oxidation can happen from the formation of very reactive free radicals species, such as hydroxyl radicals $(\mathrm{OH} \bullet)$, promoted by a radiation source (M-BRA et al., 2019; LI et al., 2017; POURAKBAK et al., 2016). They are mainly characterized by the non-selectivity and the use of potent oxidant species, as hydrogen peroxide $\left(\mathrm{H}_{2} \mathrm{O}_{2}\right)$, or semiconductors, as titanium dioxide $\left(\mathrm{TiO}_{2}\right)$, in the radical generation (ROZAS et al., 2016; MOREIRA et al., 2017).

In the heterogeneous photocatalysis, the $\mathrm{TiO}_{2}$ has been used in aqueous medium dispersed or immobilized on some support surface. Its use in dispersion arrangement in aqueous medium is energetically more efficient because of the higher contact area available for the catalyst. However, the immobilized form presents the advantage that it is not necessary to separate dispersed $\mathrm{TiO}_{2}$ particles in the end of treatment (BARROS et al., 2014).

In order to avoid this disadvantage, recent studies utilized diverse materials for $\mathrm{TiO}_{2}$ immobilization, such as glass (CUNHA et al., 2018; OBLAK et al., 2018), polymeric membranes (BARROS et al., 2014; MUKHERJEE et al., 2014), concrete (DELNAVAZ et al., 2015) and metallic supports (MOZIA et al., 2012). Those materials must present rugosity for catalyst particles fixation (BARROS et al., 2016) and good adherence to prevent leaching after immobilization (CUNHA et al., 2018).

During the studies of advanced oxidation processes is common the lack of knowledge about every existent reaction in the degradation. Many times the degradation kinetic is approximated by a pseudo-first order model, as observed in several works (AJMAL et al., 2016; KUMAR et al., 2018; SOLEYMANI; CHAHARDOLI; KAYKHAII, 2016). Nonetheless this approximation does not consider the actual degradation process complexity. One modeling technique utilized when knowledge is not available about a complex process is the Artificial Neural Network (ANN) (ROCHA et al., 2017; DAS, MAITY AND BASU, 2014). The interesting feature in neural networks is the ability to learn from experimental data exposed to them, and thus to generate a model that can approximate any curve (CSÁJI, 2001).

The ANN are able to fit in a phenomenon behavior when submitted to the experimental conditions of the process to be modeled, without the phenomenon knowledge involved in the process. The ANN has been applied to solve hard problems that would not be solved by other methods. The neural networks can model one- and multidimensional cases, what make them a practical tool to analyze kinetic patterns of complex reactions, as in this work, as well as in other academic works, for example Rocha et al. (2017) and Das, Maity and Basu (2014).

This work objective was to evaluate the efficiency of aluminum soda can seals (post-consumer recycled material) as support materials (sp) for $\mathrm{TiO}_{2}$ films in the degradation through heterogeneous photocatalysis of the dye Remazol golden yellow RNL 150 (RGY 150), a synthetic dye commonly used by the textile industry. The usage of aluminum seals as $\mathrm{TiO}_{2}$ support presents economic and environmental perspectives, once the material is abundant and has low cost and aimed mechanical properties. The degradation evaluation was realized by kinetic modeling for different reaction orders and by Artificial Neural Networks.

\section{Materials and Methods}

In the degradation assays, the textile dye Remazol golden yellow RNL 150 (RGY 150), obtained from F. Trajano Aromas e Ingredientes LTDA was used. The titanium dioxide was obtained from Evonik Degussa LTDA, comprising $75 \%$ of anatase and $25 \%$ of rutile, with superficial area of $50 \mathrm{~m}^{2} \cdot \mathrm{g}^{-1}$ and particle size of 20 $\mathrm{nm}$. The hydrogen peroxide $50 \%\left(\mathrm{v} \cdot \mathrm{v}^{-1}\right)$ was obtained from Coremal Pochteca ${ }^{\odot}$.

\section{$2.1 \mathrm{TiO}_{2}$ calcination and immobilization in aluminum nets}

Supports crafted from aluminum seals were prepared from post-consumer soda cans. The can seals were cleaned and washed with distilled water. The nets were acidified with $\mathrm{HCl} 37 \%$ for 20 seconds, succeeding to calcination at $490^{\circ} \mathrm{C}$ in muffle (SPLABOR, SP-1200DRP7) for 26 hours before $\mathrm{TiO}_{2}$ immobilization.

In the next, $\mathrm{TiO}_{2}$ immobilization on the calcined aluminum nets was carried out by the methodology described by Barros et al. (2014). The total immobilized quantity was $100 \mathrm{mg}$ of catalyst in each support. After $\mathrm{TiO}_{2}$ immobilization, the samples were taken to muffle at $490^{\circ} \mathrm{C}$ for 4 fours for best catalyst adherence on support.

\subsection{Characterization of aluminum supports}

The samples were analyzed in an XRD-6000 diffractometer from SHIMADZU, with radiation $\mathrm{Cu} \mathrm{K} \alpha(\lambda=$ $1.5418 \AA$ ) using Nickel filter as a monochromator, power of $2 \mathrm{kVA}$, voltage of $30 \mathrm{kV}$ and electric current of $30 \mathrm{~mA}$. The scanning analyses were realized in the $2 \theta$ range from $20^{\circ}$ to $80^{\circ}$, step of $0.02^{\circ}$ and velocity of $2^{\circ} . \mathrm{s}^{-1}$. The characteristic peaks of the materials were compared with the crystallographic charts 21-1272 and 21-1276 (International Center for Diffraction Data) and the aluminum 
rings crystallography prior to the $\mathrm{TiO}_{2}$ immobilization. The morphological evaluation of the aluminium support nets before and after acidification and calcination, and after $\mathrm{TiO}_{2}$ immobilization was performed by Scanning Electron Microscopy (SEM, Tescan MIRA3).

\subsection{Preliminary tests}

Before each experiment in which $\mathrm{TiO}_{2}$ was involved, the solution was kept in catalyst contact without radiation, under stirring, in order to reach the adsorption equilibrium. The systems $\mathrm{UV}, \mathrm{UV} / \mathrm{TiO}_{2}, \mathrm{UV} / \mathrm{H}_{2} \mathrm{O}_{2}, \mathrm{UV} /$ $\mathrm{H}_{2} \mathrm{O}_{2} / \mathrm{TiO}_{2}, \mathrm{UV} / \mathrm{TiO}_{2 \text { sp' }}, \mathrm{UV} / \mathrm{H}_{2} \mathrm{O}_{2} / \mathrm{TiO}_{2 \mathrm{sp}}$, where sp means supported catalyst systems were evaluated in the degradation processes. The amount of $\mathrm{TiO}_{2}$ and $\mathrm{H}_{2} \mathrm{O}_{2}$ utilized was $100 \mathrm{mg}$ and $1.59 \mathrm{mmol} . \mathrm{L}^{-1}$, respectively. The $\mathrm{TiO}_{2}$ mass used was based on the methodology described by Nascimento Júnior et al. (2018) and the $\mathrm{H}_{2} \mathrm{O}_{2}$ concentration in stoichiometric calculus.

The tests were carried out in a photocatalytic batch reactor, that contains a UV lamp (245 nm) with power of $0.830 \mathrm{~mW} \cdot \mathrm{cm}^{-2}$. The lamps were turned on 30 minutes before the experiments beginning for radiation stabilization. In cylindrical glass containers (height of $8,5 \mathrm{~cm}$ and diameter of $9,0 \mathrm{~cm}$ ), $300 \mathrm{~mL}$ of the dye RGY 150 in concentration of $20 \mathrm{mg} \cdot \mathrm{L}^{-1}$ were treated for 50 minutes.

\subsection{Factorial Experimental Design $\left(2^{3}\right)$}

A $2^{3}$ factorial experimental design was conducted for the best system obtained in the preliminary batch tests. The studied parameters were $\mathrm{H}_{2} \mathrm{O}_{2}$ concentration, $\mathrm{TiO}_{2}$ mass and degradation time. The $2^{3}$ factorial design center point was done in triplicate as a means to determine the error, totalizing 11 experiments. The studied levels are described in Table 1.

Table 1 - Variables levels of the $2^{3}$ factorial design

\begin{tabular}{lccc}
\hline Levels & $\mathrm{TiO}_{2}(\mathrm{mg})$ & $\mathrm{H}_{2} \mathrm{O}_{2}\left(\mathrm{mmol}^{\mathrm{L} \mathrm{L}^{-1}}\right)$ & Time $(\mathrm{min})$ \\
\hline-1 & 100 & 1.59 & 15 \\
0 & 150 & 5.21 & 25 \\
+1 & 200 & 8.04 & 35 \\
\hline
\end{tabular}

The Pareto diagram and the response surface methodology were used afterwards to evaluate the statistical significance of the variables, based on the work of Barros Neto et al. (2010), through the program Statistic 6.0 (SANTOS et al., 2018).

\subsection{Kinetic Study}

A kinetic study was performed with the best conditions found in the factorial experimental design. The degradation kinetic was adjusted to the pseudo-first order, pseudo-second order and pseudo-third order models (Equations 1 to 4), by the software Excel $2013^{\circ}$. In the equations, $\mathrm{C}$ is the concentration for time $t$ and $\mathrm{C}_{0}$ is the initial concentration. For the kinetic study, the correlation coefficient $\left(R^{2}\right)$ for each studied order was determined and the velocity constant $\left(\mathrm{k}_{\mathrm{app}}\right)$ and the time of half-life $\left(t_{1 / 2}\right)$ of the photocatalytic reaction were obtained. The time of half-life was found by the Equation 6 .

$$
\begin{aligned}
& \frac{d C}{d t}=-k C \stackrel{n=1}{\longrightarrow} C=C_{0} e^{-k t} \\
& \frac{d C}{d t}=-k C^{n} \stackrel{n \neq 1}{\longrightarrow} C=\sqrt[1-n]{(\mathrm{n}-1) \mathrm{kt}+C_{0}} \\
& n=2, \quad C(\mathrm{t}=0) / C_{0}=1 \longrightarrow C=\frac{1}{k t+1} \\
& n=3, \quad C(\mathrm{t}=0) / C_{0}=1 \longrightarrow C=\frac{1}{\sqrt{2 k t+1}} \\
& \mathrm{n}=1, \quad \ln \frac{[\mathrm{C}]}{\left[\mathrm{C}_{0}\right]}=-k t \\
& t_{\frac{1}{2}}=\frac{\ln 2}{k}
\end{aligned}
$$

The kinetic model using ANN was also stablished for the best factorial design conditions. The ANN was constructed using time as the input value and dimensionless concentration as the output, generating a curve of concentration depending on time, according to other authors such as Göb et al. (1999), Giroto et al. (2006), Rocha et al. (2017) and Das, Maity and Basu (2014). The software utilized for the neural adjustment was developed by the research group through Unity $3 \mathrm{D}^{\circ}$. The ANN is composed by input, hidden layers and output with different structure and number of neurons. The chosen net structure was 1:2:1 (one input variable, time, one hidden layer with two neurons and one output variable).

The achieved software was able to adjust this neural network to real data in the learning stage. The learning method was based on the particles swarm optimization, random search and genetic algorithm, partial and initially presented by Kennedy and Eberhart (1995). The error criteria applied was the mean absolute error for the studied system. A feedforward neural network was used and the activation function adopted was sigmoid between 1 and -1. To realize the ANN analysis, the input and output values were normalized and stablished between -1 and $1(t=0$ and $t=35 \mathrm{~min})$. Furthermore, the output concentrations $\left(C / C_{0}=0\right.$ e $\left.C / C_{0}=1\right)$ were renormalized, lest the training makes the network goes away to a saturation zone, as exposed by Haikin (1999). The training time utilized was 600 seconds to reach a limit residual error.

\subsection{Toxicity assays}

The toxicity assay consisted to expose lettuce seeds of the species Lactuca Sativa (obtained from Feltrin Semen- 
tes, Brasil) to dye samples and the best treatment system observed in the studies, following Meyer et al. (1982). The negative control was done with distilled water and the positive with boric acid solution (3\%). The assay was carried out five times. The seeds were exposed to the dye and its treatment for 120 hours in the dark and temperature at $22{ }^{\circ} \mathrm{C}$. The radicles growth, the inhibition rate and the inhibition concentration of the radicle growth for $50 \%$ of organisms $\left(\mathrm{IC}_{50}\right)$ were calculated.

\section{Results and Discussion}

\subsection{Characterization of the aluminum support}

The XRD spectrums of $\mathrm{TiO}_{2}(100 \mathrm{mg})$ immobilized in aluminum support are showed in Figure 1. The qualitative interpretation of the compounds present in the catalyst was realized based on the Inorganic Crystal Structure Database (ICSD): 21-1272 e 21-1276.
Figure 1 - XRD diffractogram of $\mathrm{TiO}_{2}$ immobilized in aluminum nets (anatase $(A)$, rutile $(R)$ e aluminum $(A I)$ )

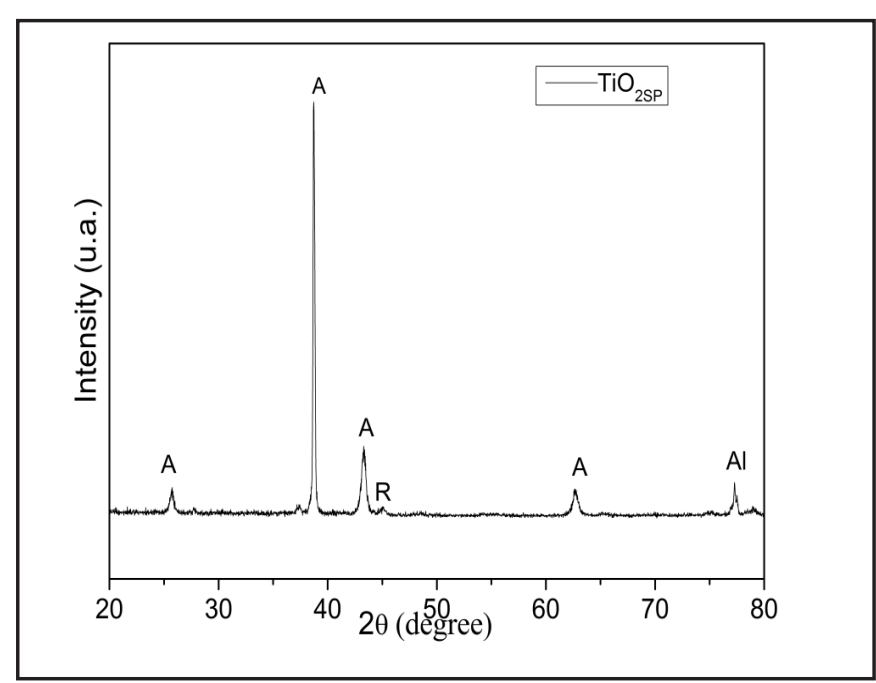

Figure 2 - SEM analyses for a) aluminum support, b) acidified and calcined aluminum support and c) $\mathrm{TiO}_{2}$ supported in aluminum net.

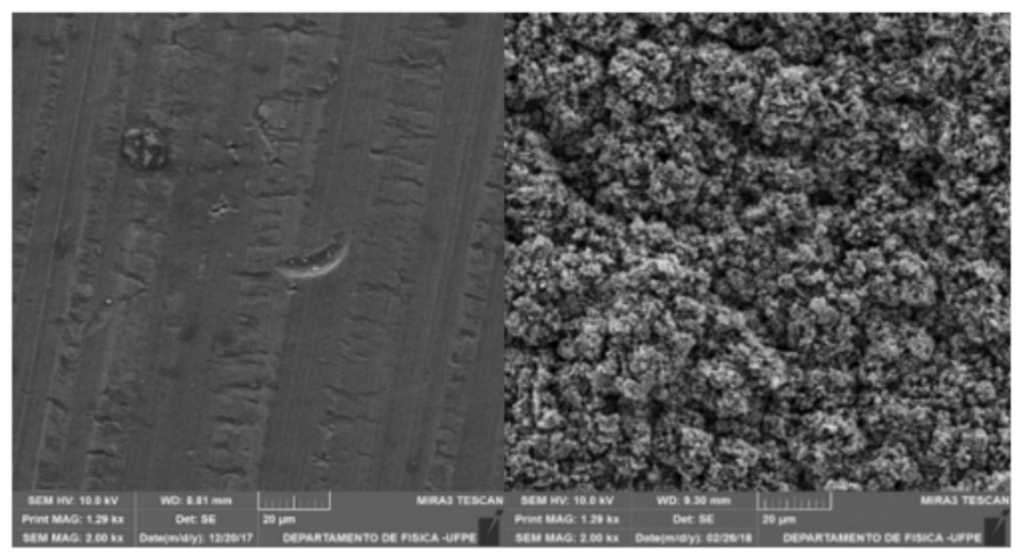

(a)

(b)

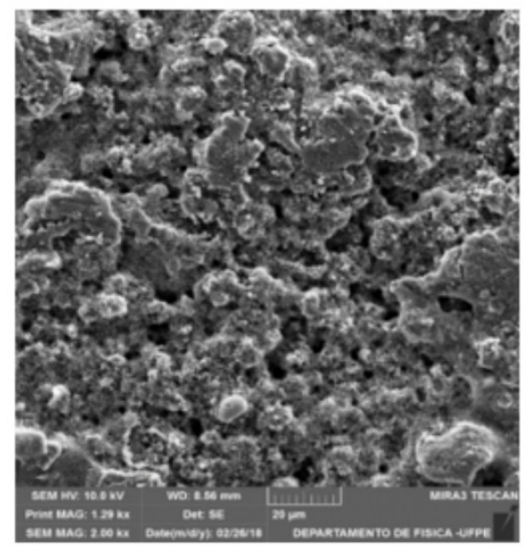

(c) 
It is observed in Figure 1 the presence of the $\mathrm{TiO}_{2}$ anatase and rutile phases, as well as the metallic substrate of aluminum (nets). The peaks $25.53^{\circ}(101), 38.60^{\circ}(112)$, $43.22^{\circ}(200)$ and $62.6^{\circ}(204)$ are referred to the anatase phase (JCPDS 00-021-1272) for different crystal plans. The rutile phase (JCPDS 00-021-1276) is represented by the peak $44.77^{\circ}(210)$. The peak in $77.24^{\circ}$ is probably related to the metallic substrate of aluminum.

The SEM scans displayed in Figure 2 demonstrate the aluminum support surface before calcination, after calcination and after calcination and immobilization of $100 \mathrm{mg}$ of $\mathrm{TiO}_{2}$.

In Figure 2a), it is observed that the metallic material without acidification and calcination does not present porosity, while in Figure $2 \mathrm{~b}$ ) the aluminum support is presented porous and irregular after treatments. The immobilized $\mathrm{TiO}_{2}$ layer is displayed as a uniform film (Figure 2c)) after the $\mathrm{TiO}_{2}$ distribution on the aluminum net and succeeding thermal fixation. According to Ramasundaram et al. (2015), in whose work steel wires were covered with $\mathrm{TiO}_{2}$ the material porosity after thermal treatment allowed the formation of a catalyst layer, as well as in this work. Oblak et al. (2018) used stainless steel nets for the $\mathrm{TiO}_{2}$ immobilization and the uniform distribution of material was noticed likewise.

\subsection{Preliminary tests}

In the preliminary tests, without radiation, it was observed that there was not degradation of the dye solution after 50 minutes in all studied conditions. This behavior was expected, since without radiation source, it is not possible to generate the free radicals $(\mathrm{OH} \bullet$ ) responsible for the organic dyes degradation. The same behavior was observed by Santos et al. (2018) and Nascimento Júnior et al. (2018) in their photocatalytic studies with dyes. In Figure 3, the degradation behavior of the RGY dye is represented for different AOP as a function of the experiment time.

The Figure 3 points out that the heterogeneous photocatalysis systems $\left(\mathrm{UV} / \mathrm{H}_{2} \mathrm{O}_{2} / \mathrm{TiO}_{2}\right.$ and $\left.\mathrm{UV} / \mathrm{H}_{2} \mathrm{O}_{2} / \mathrm{TiO}_{2 \text { sp }}\right)$ presented the best degradation rates among the tested systems, with efficiency of $99.93 \%$ and $93.41 \%$, respectively, for 50 minutes. The systems with combined $\mathrm{TiO}_{2}$ and $\mathrm{H}_{2} \mathrm{O}_{2}$ demonstrated the best results, what can be explained due to the synergic phenomenon that causes an increase in the global rate of radical hydroxyl generation (SALLEH et al., 2016).

The efficiency reduction for the immobilized $\mathrm{TiO}_{2}$ system was expected related to the suspended system, once the use of $\mathrm{TiO}_{2}$ dispersed in aqueous solution is energetically more efficient as a result of the larger catalyst contact area (BARROS et al., 2014; ROSTAMI-VARTOONI et al., 2016). The same behavior was noted by Alalm et al. (2016). Although the suspended system has presented best results related to degradation, the difference was only $6.52 \%$. In addition, the immobilized catalyst choice offers advantages, for instance, it facilitates its recovery in the end of the process and allows good catalyst handling (LUDWICHK et al., 2015; ERJAVEC et al., 2016; BARBOSA et al., 2019).

Figure 3 - Preliminary degradation tests for the dye RGY 150 in aqueous solution by oxidation processes under radiation UVC. $\left[\mathrm{C}_{0}\right]=20 \mathrm{mg} \mathrm{L}^{-1}(1: 1) ;\left[\mathrm{H}_{2} \mathrm{O}_{2}\right]=1.59 \mathrm{mmol}^{-\mathrm{L}^{-1}} ; \mathrm{m}_{\mathrm{TiO2}}=100 \mathrm{mg}$

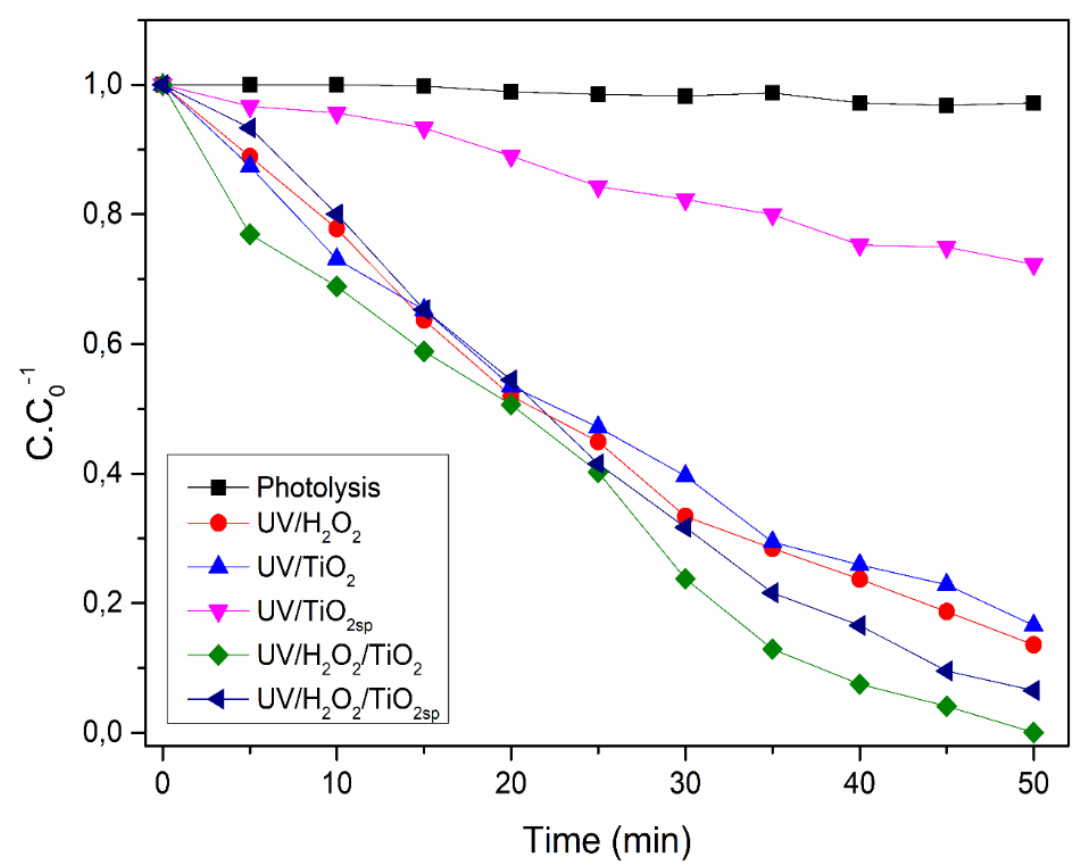




\subsection{Factorial Experimental Design $\left(2^{3}\right)$}

A $2^{3}$ factorial experimental design with center point was conducted for the system selected in the preliminary tests $\left(\mathrm{UV} / \mathrm{H}_{2} \mathrm{O}_{2} / \mathrm{TiO}_{2 \mathrm{sp}}\right)$. The utilized parameters were $\mathrm{H}_{2} \mathrm{O}_{2}$ concentration, $\mathrm{TiO}_{2}$ mass and degradation time. The conditions applied to the design and the dye removal percentage are displayed in Table 2.

Table 2 - RGY degradation for levels of a $2^{3}$ Factorial Experimental Design

\begin{tabular}{ccccc}
\hline \multirow{2}{*}{ Assay } & \multicolumn{3}{c}{ Levels } & Degradation (\%) \\
\cline { 2 - 5 } & $\mathrm{H}_{2} \mathrm{O}_{2}$ & $\mathrm{TiO}_{2}$ & Time & 27.13 \\
\hline 1 & - & - & - & 29.73 \\
2 & + & - & - & 35.25 \\
3 & - & + & - & 59.93 \\
4 & + & + & - & 71.50 \\
5 & - & - & + & 93.57 \\
6 & + & - & + & 76.80 \\
7 & - & + & + & 100.00 \\
8 & + & + & + & 70.06 \\
9 & 0 & 0 & 0 & 74.15 \\
10 & 0 & 0 & 0 & 72.23 \\
11 & 0 & 0 & 0 & \\
\hline
\end{tabular}

The assay 8 , that comprises the maximum values of every parameter in Table 2, presented the best degradation rates of RGY 150. Oancea and Meltzer (2013) perceived that the influence of the $\mathrm{H}_{2} \mathrm{O}_{2}$ amount applied for synthetic dyes removal obtained best degradation percentages for higher oxidant dosages. Also Pajootan et al. (2017), Santos et al. (2018) and Gupta et al. (2011) observed in their works that the $\mathrm{TiO}_{2}$ increase caused higher efficiency on synthetic dyes removal in aqueous solution.

A statistical analysis of the variables (parameters) significance was performed by the software Statistica Experimental Design 6.0, as displayed on the Pareto chart in Figure 4.

The interactions $\mathrm{H}_{2} \mathrm{O}_{2}$ vs $\mathrm{TiO}_{2}$ and $\mathrm{TiO}_{2}$ vs Time presented statistical significance. From the Pareto chart result, response surfaces were plotted and showed in Figure 5.

The analysis of the response surface in Figure 5b) points out that while the $\mathrm{TiO}_{2}$ concentration and reaction time rise, the dye degradation percentage also increases. Overall, the photocatalytic processes efficiency is increased with larger amounts of titanium dioxide, since there are not excessive quantities of reagent. Its excess can cause solution opacity, which hampers the radiation absorption by the system (Alalm et al., 2016; Reza et al., 2017). The effect of combined $\mathrm{TiO}_{2}$ and $\mathrm{H}_{2} \mathrm{O}_{2}$ cooperates for a higher formation of hydroxyl radicals and collaborates to avoid the recombination electron/hole (Salaeh et al., 2016). Hence, their amounts increase tend to raise the catalytic process efficiency.

According to experimental data, an empiric model was obtained as exposed by Equation 7 for the system $\mathrm{UV} / \mathrm{H}_{2} \mathrm{O}_{2} / \mathrm{TiO}_{2 \mathrm{sp}}$ by the software Statistica 6.0. This model

Figure 4 - Pareto chart for the results of the $2^{3}$ factorial experimental design for the system $U V / \mathrm{H}_{2} \mathrm{O}_{2} / \mathrm{TiO}_{2 \mathrm{sp}}$

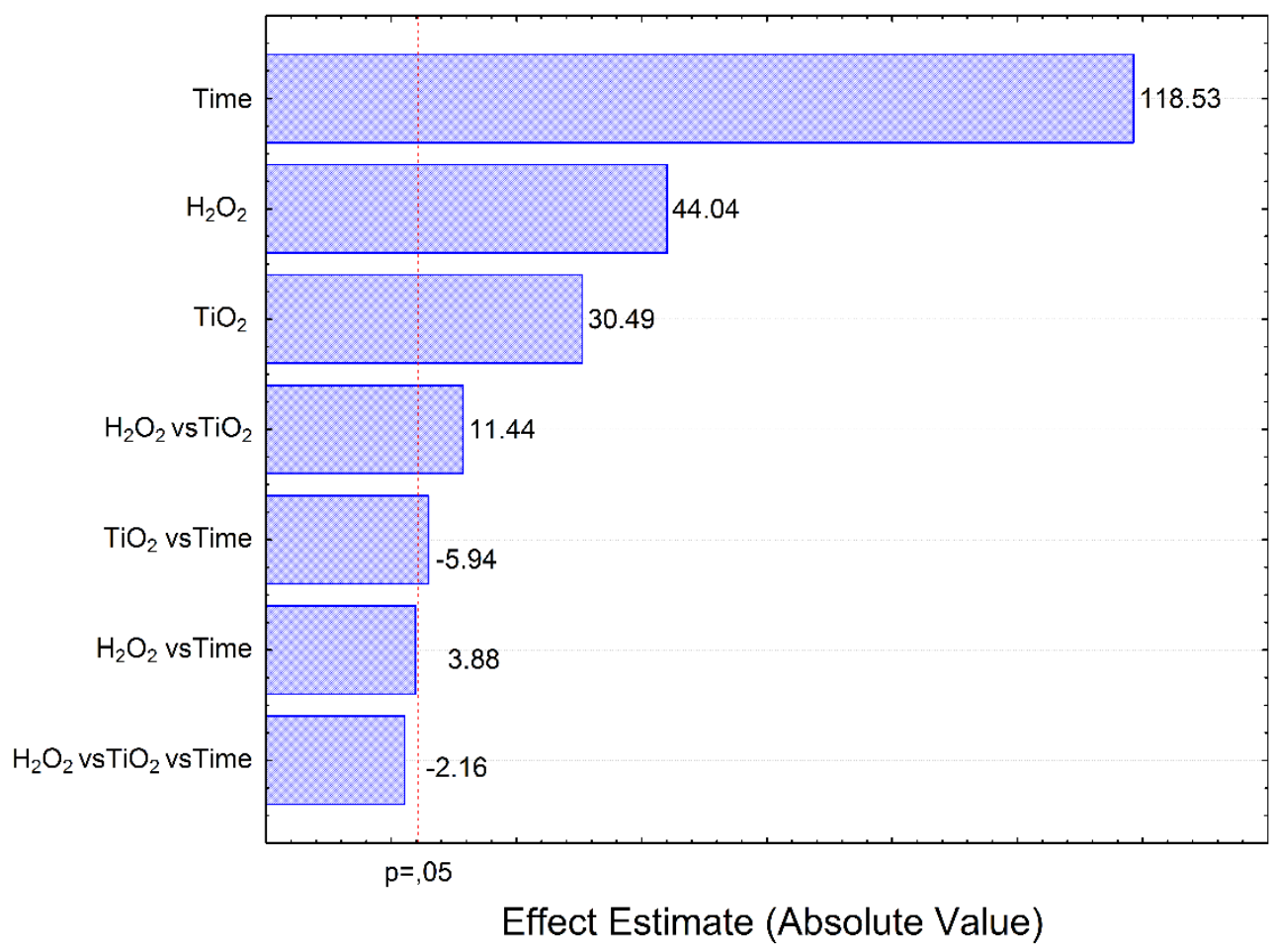


Figure 5 - Response surfaces of the dye degradation according to the variables: a) $\mathrm{TiO}_{2} \times \mathrm{H}_{2} \mathrm{O}_{2}$ and b) $\mathrm{TiO}_{2} \times \mathrm{Time}$ for the system $\mathrm{UV} / \mathrm{H}_{2} \mathrm{O}_{2} / \mathrm{TiO}_{2 \text { sp }}$

(a)

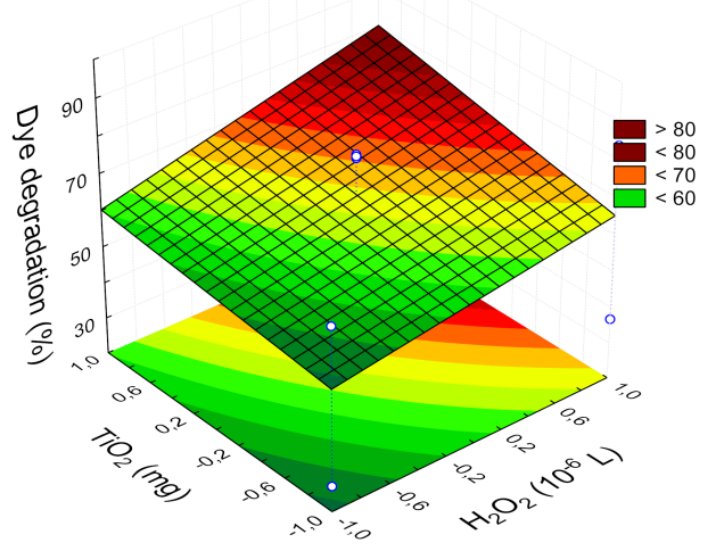

(b)

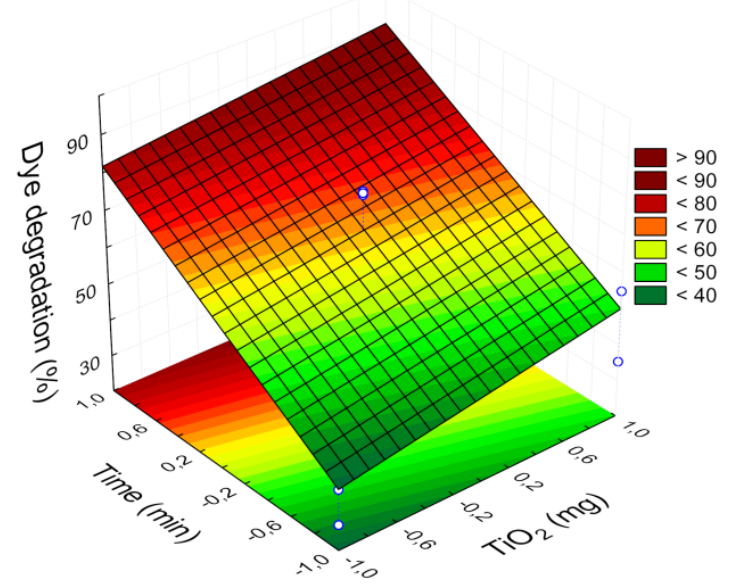

Figure 6 - Residual analysis of the empiric model for the dye solution degradation (UV-C/ $/ \mathrm{H}_{2} \mathrm{O}_{2} / \mathrm{TiO}_{25 \mathrm{~s}}$ system)

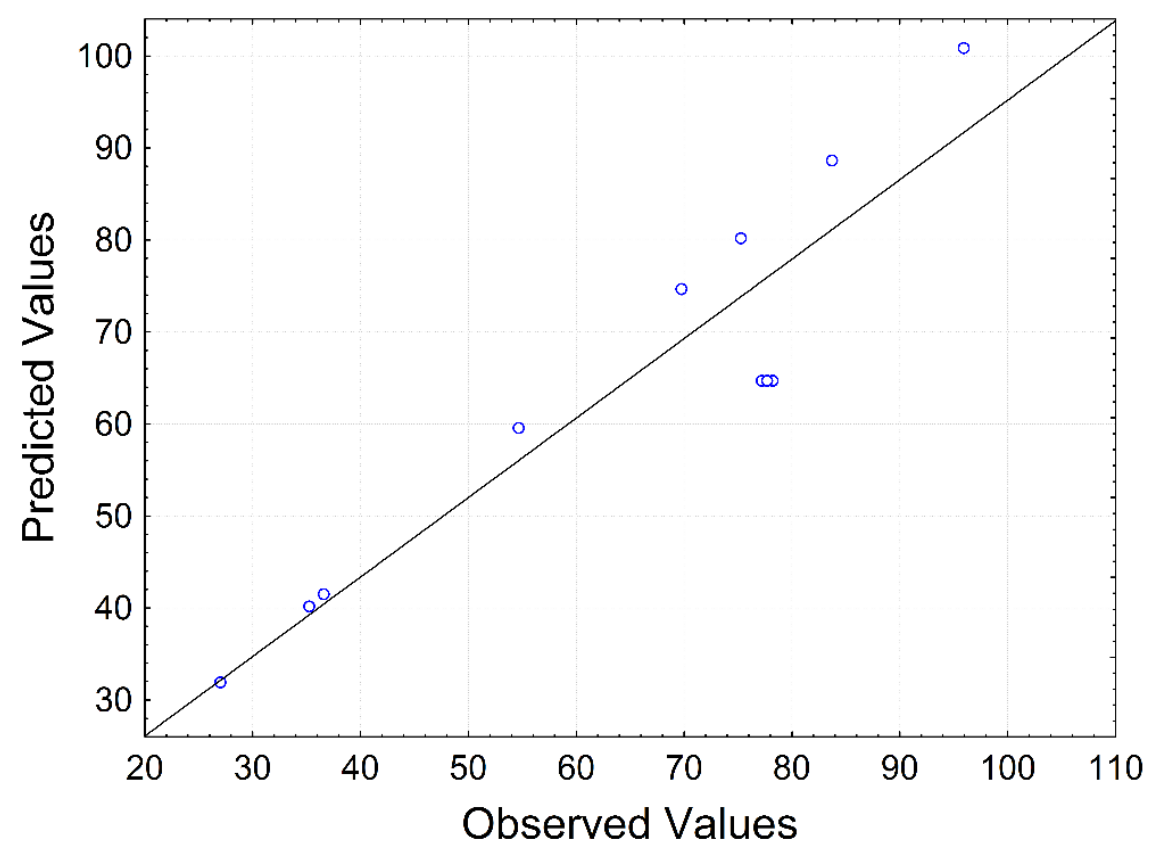


describes the dye degradation efficiency (\%), throughout the study range, for the significant variables.

$$
\begin{aligned}
& \mathrm{D}(\%)=64.67+5.50_{\mathrm{xTiO} 2}+7.95 \mathrm{X}_{\mathrm{H} 2 \mathrm{O} 2}+21.39 \mathrm{X}_{\mathrm{time}}+2.06 \mathrm{X}_{\mathrm{TiO} 2} \\
& \mathrm{X}_{\mathrm{H} 2 \mathrm{O} 2}-1.07 \mathrm{X}_{\mathrm{TiO} 2} \mathrm{X}_{\text {time }}(7)
\end{aligned}
$$

The residual analysis by software Statistica 6.0 for the experimental data of the system UV-C/ $\mathrm{H}_{2} \mathrm{O}_{2} / \mathrm{TiO}_{2 \text { sp }}$ is presented in Figure 6.

Residual analysis accessed by the $2^{3}$ factorial experimental design presented a good adjustment, with the experimental values significantly close to the predicted ones. The system pure error was 0.26 , which confirms that the observed data were adjusted adequately.

\subsection{Kinetic Study}

The degradation of RGY 150 with $\mathrm{TiO}_{2}$ supported in aluminum $\left(\mathrm{UV} / \mathrm{H}_{2} \mathrm{O}_{2} / \mathrm{TiO}_{2 \mathrm{sp}}\right)$ was studied in the best conditions of the factorial design. Figure 7 shows the reaction kinetic for this system.

From Figure 7, it is possible to observe that more than $95 \%$ of the color was removed until 20 minutes of treatment. At 30 minutes, $98 \%$ of the dye was degraded. The index of $100 \%$ of degradation was reached in the end of 35 minutes of treatment.

Three kinetic models (pseudo-first order, pseudo-second order and pseudo-third order) were tested in order to obtain a general trend model. The pseudo-first order model reached $0.114 \mathrm{~min}^{-1}$ for the kinetic velocity constant, $\mathrm{k}$, and 0.994 for the correlation coefficient, $\mathrm{R}^{2}$. The time of half-life estimated for the system was 7.93 minutes.

However, as seen in Figure 7 for the pseudo-second and pseudo-third order models, adjustments of superior order do not fit in experimental data as satisfactory as pseudo-first order curve. This can be proved by the parameters values obtained in the adjustments: in the pseudo-second order model, the $\mathrm{R}^{2}$ was 0.8438 and in the pseudo-third order model, it was 0.7534 , both lesser values that the one reached in Figure 6 by the pseudo-first order model. The superior order unfitness indicates that the pseudo-first order is the best adjustment for the tested set of models, what is also perceived in other works of AOP application for dye degradation (AJMAL et al., 2016; KUMAR et al., 2018; SOLEYMANI; CHAHARDOLI; KAYKHAII, 2016).

The neural network resultant of the training with the degradation experimental data and its adjustment to them are displayed in Figure 8.

In Figure 8a), the input layer is related to normalized time values that generates concentration values, also normalized, as a result. During the calculus, the network multiply the input value times the weights (values above the lines that connect the neurons) and sum up to the bias (values above neurons). The value is then computed by the activation sigmoid function to get a result that is newly multiplied by a weight and succeeds to the next layer. Consequently the result is generated. This model is able to predict the dye degradation development in the given conditions.

The concordance between experimental and ANN predicted data is noted in Figure $8 \mathrm{~b}$ ). The mean absolute error was 0.0181 , leading to a determination coefficient $\mathrm{R}^{2}$ of 0.9967 . This value is higher than the one observed in the pseudo-first order adjustment, what demonstrates that the neural network model can better describe the degradation behavior.

Figure 7 - Pseudo-first order, Pseudo-second order and Pseudo-third order kinetics for the photocatalytic degradation of the dye RGY 150

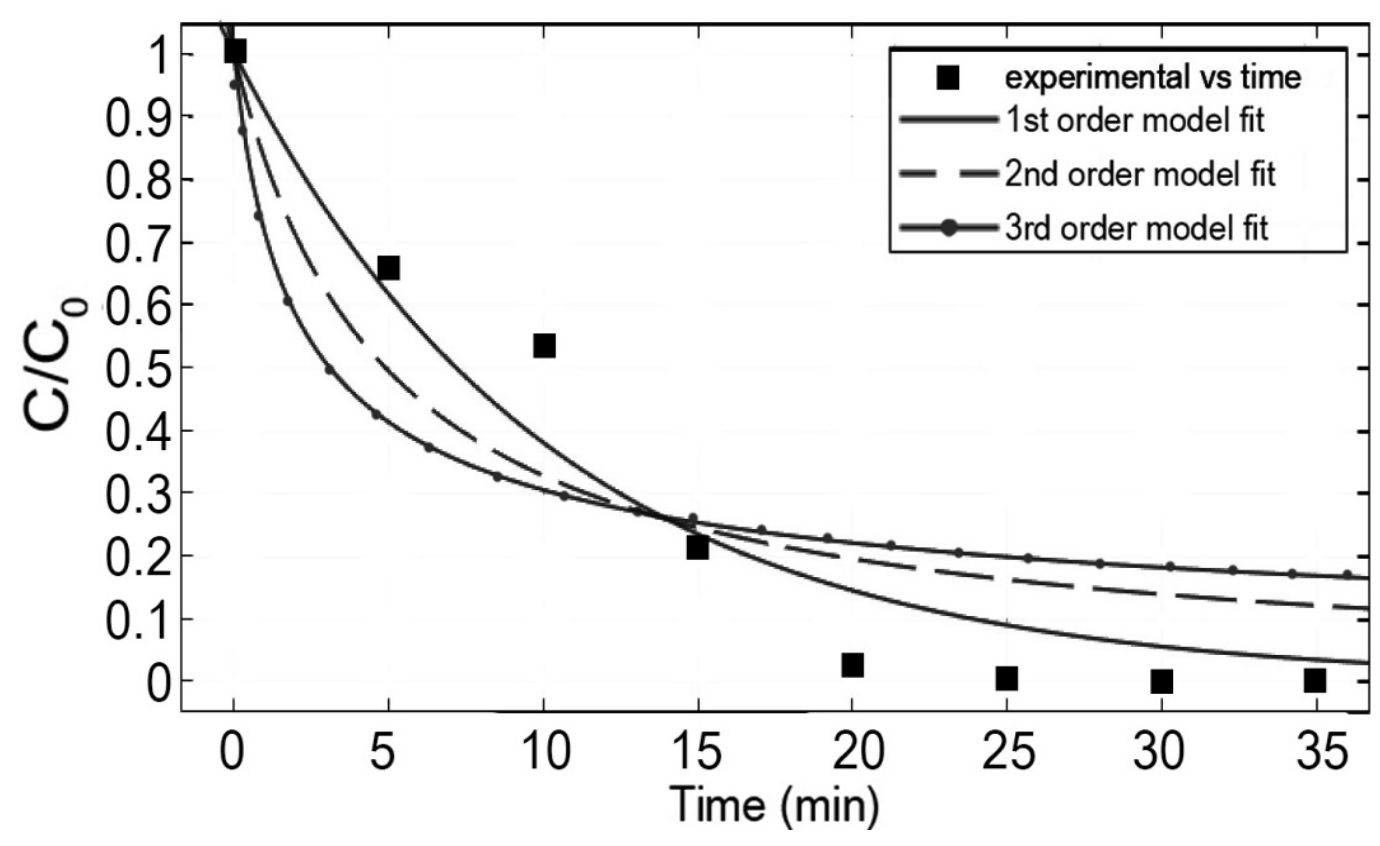


Figure 8 - a) ANN resultant from training with best condition data of the factorial design and (b) comparison between experimental and ANN data.
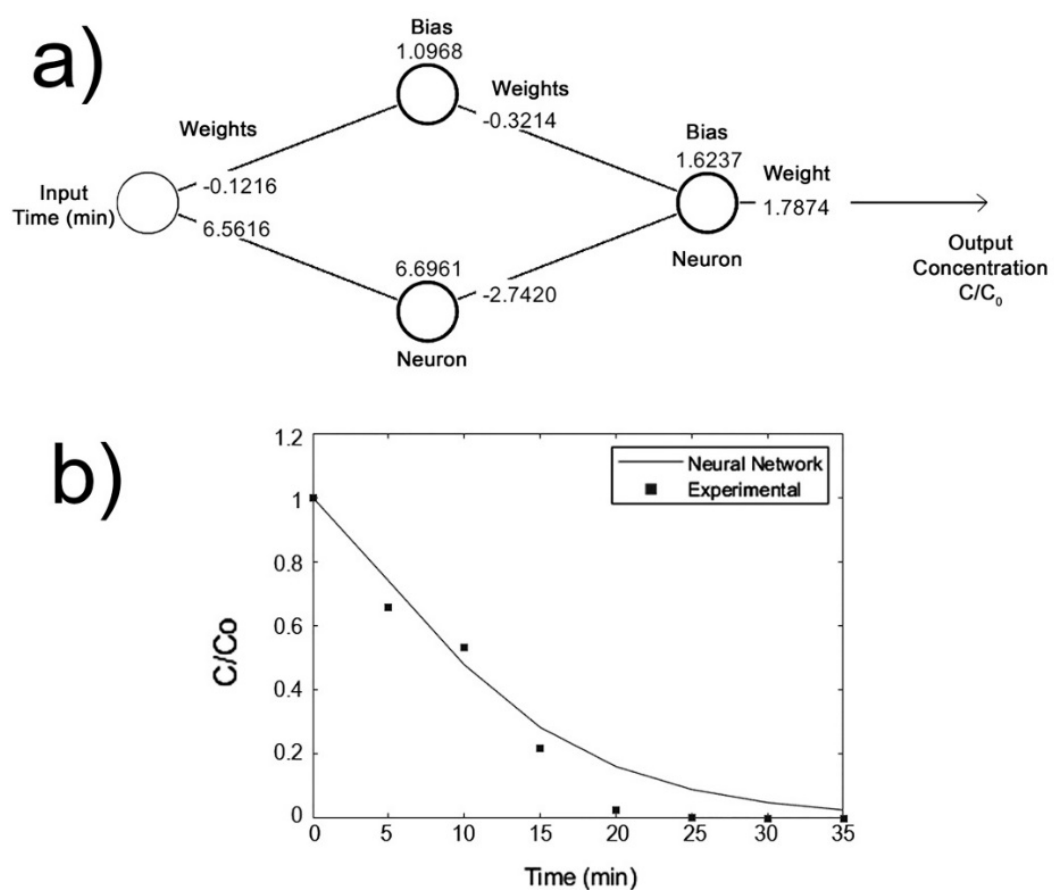

\subsection{Toxicity assays}

From the phytotoxicity bioassay, it was calculated the inhibition concentration for $50 \%$ of organisms exposed to the dye solution and the conditions with best results of the degradation studies. The radicle extent growth of Lactuca sativa in the dye solution and in its respective treatments was compared to the positive and negative control. The parameters germination, radicle length and $\mathrm{IC}_{50}$ are displayed in Table 3.

Table 3 - Resultant parameters from the toxicity assay with Lactuca sativa.

\begin{tabular}{lccc}
\hline \multicolumn{1}{c}{ Sample } & $\begin{array}{c}\text { Germination } \\
(\%)\end{array}$ & $\begin{array}{c}\text { Radicle } \\
\text { length }(\mathrm{cm})\end{array}$ & $\begin{array}{c}\mathrm{IC}_{50} \\
\left(\mathrm{mg}^{\mathrm{L}-1}\right)\end{array}$ \\
\hline $\begin{array}{l}\text { Without } \\
\text { treatment }\end{array}$ & 93 & $2.1 \pm 0.1$ & $17.8 \pm 0.2$ \\
$\begin{array}{l}\text { Post-treatment } \\
\text { Positive Control }\end{array}$ & 98 & $2.7 \pm 0.2$ & $22.5 \pm 0.1$ \\
$\begin{array}{l}\text { Negative } \\
\text { Control }\end{array}$ & 100 & $3.6 \pm 0.2$ & - \\
\hline
\end{tabular}

${ }^{\text {aRGY }} 150$ Solution $20 \mathrm{mg} . \mathrm{L}^{-1}$

${ }^{b}$ Distilled water

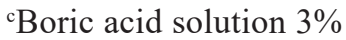

It was observed, by Table 3, that the treatments applied to the dye solution decreased the acute phytotoxicity, once the $\mathrm{IC}_{50}$ is inversely proportional to the toxicity. The negative control did not present germination and there was a growth of $0.6 \mathrm{~cm}$ for the sample after photocatalytic treatment comparing to the not treated sample. In the work of Santos et al. (2018), that studied the removal of the synthetic dyes bright blue and erythrosine $\left(60 \mathrm{mg} . \mathrm{L}^{-1}\right)$ with titanium dioxide, a length variation of $0.43 \mathrm{~cm}$ between the treated and not treated samples was observed.

\section{Conclusion}

In the preliminary tests, a best behavior was observed for systems with combined $\mathrm{TiO}_{2}$ and $\mathrm{H}_{2} \mathrm{O}_{2}$. In comparison with the suspended $\mathrm{TiO}_{2}$ system, the catalyst supported on aluminum nets presents close dye degradation rates and does not need recovery procedures afterwards, what is an operational advantage. In the $2^{3}$ factorial design for the supported catalyst system, the parameters amounts increase made the system more efficient, with good statistical significance and $100 \%$ of degradation in 35 minutes. With the best conditions $\left(\mathrm{m}_{\mathrm{TIO} 2}=200 \mathrm{mg},\left[\mathrm{H}_{2} \mathrm{O}_{2}\right]\right.$ $=8.04 \mathrm{mmol} \cdot \mathrm{L}^{-1}, 35$ minutes), a kinetic study was carried out and the system was better adjusted to the pseudo-first order model. The following kinetic coefficients were obtained: $\mathrm{k}=0.114 \mathrm{~min}^{-1}, \mathrm{R}^{2}=0.994 \mathrm{e} \mathrm{t}_{1 / 2}=7.93$ minutes. The neural network model presented still better results with the determination coefficient of $R^{2}=0.9967$. The degradation also diminishes the toxicity, what was proved by the phytotoxicity bioassay with lettuce seeds. The immobilized $\mathrm{TiO}_{2}$ use is positive because is an ecological alternative due to the minimization of $\mathrm{TiO}_{2}$ removal cost and the utilization of recycled material. 


\section{References}

AJMAL, A.; MAJEED, I.; MALIK, R. N.; IQBAL, M.; NADEEM, M. A.; HUSSAIN, I.; NADEEM, M. A. Photocatalytic degradation of textile dyes on $\mathrm{Cu}_{2} \mathrm{O}-$ $\mathrm{CuO} / \mathrm{TiO}_{2}$ anatase powders. Journal of Environmental Chemical Engineering, v. 4, p. 2138-2146, 2016.

ALINSAFI, A.; EVENOU, F.; ABDULKARIM, E. M.; PONS, M. N.; ZAHRAA, O.; BENHAMMOU, A.; NEJMEDDINE, A. Treatment of textile industry wastewater by supported photocatalysis. Dyes and Pigments, v. 74, p. 439-445, 2007.

ASGHAR, A.; RAMAN, A. A. A.; DAUD, W. M. A. W. Advanced oxidation processes for in-situ production of hydrogen peroxide/hydroxyl radical for textile wastewater treatment: A review. Journal of Cleaner Production, v. 87, p. 826-838, 2015.

BARBOSA, A. A.; AQUINO, R. V. S.; OLIVEIRA, A. F. B.; DANTAS, R. F.; SILVA, J. P.; DUARTE, M. M. M. B.; ROCHA, O. R. S. Development of a new photocatalytic reactor built from recyclable material for the treatment of textile industry effluents. Desalination and Water Treatment, v. 151, p. 82-92, 2019.

BARROS, A. L.; DOMINGOS, A. A. Q.; FECHINE, P. B. A.; KEUKELEIRE, D.; NASCIMENTO, R. F. PET as a Support Material for $\mathrm{TiO}_{2}$ in Advanced Oxidation Processes. Journal Applied Polymer Science, v. 131, p. 1-9, 2014.

BARROS NETO, B.; SCARMINIO, I. S.; BRUNS, R. E. Como fazer experimentos: pesquisa e desenvolvimento na ciência e na indústria, 4. Ed. Porto Alegre, Brazil: Bookman, 2010. 414 p.

BORGES, S.S.; XAVIER, L.P.S.; SILVA, A.C.; AQUINO, S.F. Immobilized titanium dioxide $\left(\mathrm{TiO}_{2}\right)$ in different support materials to use in heterogeneous photocatalysis. Química Nova, v. 39, p. 836-844, 2016.

CSÁJI, B. C. Approximation with Artificial Neural Networks. Faculty of Sciences. Eötvös Loránd University, Hungary, 2001.

CUNHA, D. L.; KUZNETSOV, A.; ACHETE, C. A.; MACHADO, A. E. H.; MARQUES, M. Immobilized $\mathrm{TiO}_{2}$ on glass spheres applied to heterogeneous photocatalysis: photoactivity, leaching and regeneration process. PeerJ, v. 6, p. 4464-4483, 2018.

DAS, L.; MAITY, U.; BASU, J. K. The photocatalytic degradation of carbamazepine and prediction by artificial neural networks. Process Safety and Environmental Protection, v. 92, p. 888-895, 2014.
DELNAVAZ, M; AYATI, B.; GANJIDOUST, H.; SANJABI, S. Application of concrete surfaces as novel substrate for immobilization of $\mathrm{TiO}_{2}$ nano powder in photocatalytic treatment of phenolic water. Journal of Environmental Health Science and Engineering, v. 13, p. 58-68, 2015.

ERJAVEC, B.; HUDOKLIN, P.; PERC, K.; TIŠLER, T.; DOLENC, M. S.; PINTAR, A. Glass fiber-supported $\mathrm{TiO}_{2}$ photocatalyst: Efficient mineralization and removal of toxicity/estrogenicity of bisphenol A and its analogs. Applied Catalysis B: Environmental, v. 183, p. 149-158, 2016.

ALALM, M. G; TAWFIK, A.; OOKAWARA, S. Enhancement of photocatalytic activity of $\mathrm{TiO}_{2}$ by immobilization on activated carbon for degradation of pharmaceuticals. Journal of Environmental Chemical Engineering, v. 4, p. 1929-1937, 2016.

GIROTO, J. A.; GUARDANI, R.; TEIXEIRA, A. C. S. C.; NASCIMENTO, C. A. O. Study on the photo-Fenton degradation of polyvinyl alcohol in aqueous solution. Chemical Engineering and Processing, v. 45, p. 523$532,2006$.

GÖB, S.; OLIVEROS, E.; BOSSMANN, S. H.; BRAUN, A. M.; GUARDANI, R.; NASCIMENTO, C. A. O. Modeling the kinetics of a photochemical water treatment process by means of artificial neural networks. Chemical Engineering and Processing, v. 38, p. 373-382, 1999.

GUPTA, V. K.; JAIN, R.; NAYAK, A.; AGARWAL, S.; SHRIVASTAVA, M. Removal of the hazardous dye Tartrazine by photodegradation on titanium dioxide surface. Materials Science and Engineering: C, v. 31, p. 1062-1067, 2011.

HAIKIN, S. Neural Networks: A Comprehensive Foundation, 1. ed. Delhi, India: Pearson Education, 1999. $482 \mathrm{p}$.

HASSAAN, M. A.; NEMR, A. E. Health and Environmental Impacts of Dyes: Mini Review. American Journal of Environmental Science and Engineering, v. 1, p. 6467, 2017.

KENNEDY, J.; EBERHART, R. Particle swarm optimization. IEEE International Conference (1995).

KUMAR, M. S.; SONAWANE, S. H.; BHANVASE, B. A.; BETHI, B. Treatment of ternary dye wastewater by hydrodynamic cavitation combined with other advanced oxidation processes (AOP's). Journal of Water Process Engineering, v. 23, p. 250-256, 2018. 
LI, F.; HUANG, J.; XIA, Q.;LOU, M.;YANG, B.;TIAN, Q.;LIU, Y. Direct contact membrane distillation for the treatment of industrial dyeing wastewater and characteristic pollutants. Separation and Purification Technology, v. 195, p. 83-91, 2018.

LUDWICHK, R.; HELFERICH, O. K.; KIST, C. P.; LOPES, A. C.; CAVASOTTO, T.; SILVA, D. C.; BARRETORODRIGUES, M. Characterization and photocatalytic treatability of red water from Brazilian TNT industry. Journal of Hazardous Materials, v. 293, p. 81-86, 2015.

M'BRA, C. I.; GARCÍA-MUÑOZ, P.; DROGUI, P.; KELLER, N.; TROKOUREY, A.; ROBERT, D. Heterogeneous photodegradation of Pyrimethanil and its commercial formulation with $\mathrm{TiO}_{2}$ immobilized on $\mathrm{SiC}$ foams. Journal of Photochemistry and Photobiology A: Chemistry, v. 368, p. 1-6, 2019.

MEYER, B.; FERRIGNI, N.; PUTNAM, J.; JACOBSEN, L.; NICHOLS, D.; MCLAUGHLIN, J. Brine Shrimp: A Convenient General Bioassay for Active Plant Constituents. PlantaMedica, v. 45, p. 31-34, 1982.

MOREIRA, F. C.; BOAVENTURA, R. A. R.; BRILLAS, E.; VILAR, V. J. P. Electrochemical advanced oxidation processes: A review on their application to synthetic and real wastewaters. Applied Catalysis B: Environmental, v. 202, p. 217-261, 2017.

MOZIA, S.; BROZEK, P.; PRZEPIORSKI, J.; TRYBA, B.; MORAWSKI, A. W. Immobilized $\mathrm{TiO}_{2}$ for Phenol Degradation in a Pilot-Scale Photocatalytic Reactor. Journal of Nanomaterials, v. 2012, p. 1-10, 2012.

MUKHERJEE, D.; BARGHI, S.; RAY, A. Preparation and characterization of the $\mathrm{TiO}_{2}$ immobilized polymeric photocatalyst for degradation of aspirin under UV and Solar Light. Processes, v. 2, p. 12-23, 2014.

NASCIMENTO JÚNIOR, W. J.; ROCHA, O. R. S.; DANTAS, R. F.; SILVA, J. P.; BARBOSA, A. A. Kinetic study of food dyes removal from aqueous solutions by solar heterogeneous photocatalysis with artificial neural networks and phytotoxicity assessment. Desalination and Water Treatment, v. 104, p. 304-314, 2018.

OANCEA, P.; MELTZER, V. Photo-Fenton process for the degradation of Tartrazine (E102) in aqueous medium. Journal of the Taiwan Institute of Chemical Engineers, v. 44, p. 990-994, 2013.

OBLAK, R.; KETE, M.; TASBIHI, M. Alternative support materials for titaniaphotocatalyst towards degradation of organic pollutants. Journal of Water Process Engineering, v. 23, p. 142-150, 2018.
PAJOOTAN, E.; RAHIMDOKHT, M.; ARAMI, M. Carbon and CNT fabricated carbon substrates for $\mathrm{TiO}_{2}$ nanoparticles immobilization with industrial perspective of continuous photocatalytic elimination of dye molecules. Journal of Industrial and Engineering Chemistry, v. 55, p. 149-163, 2017.

POURAKBAR, M.; MOUSSAVI, G.; SHEKOOHIYAN, S. Homogenous VUV advanced oxidation process for enhanced degradation and mineralization of antibiotics in contaminated water. Ecotoxicology and Environmental Safety, v. 125, p. 72-77, 2016.

RAMASUNDARAM, S., SON, A., SEID, M. G., SHIM, S., LEE, S. H., CHUNG, Y. C, HONG, S. W. Photocatalytic applications of paper-like poly(vinylidene fluoride)titanium dioxide hybrids fabricated using a combination of electrospinning and electrospraying. Journal of Hazardous Materials, v. 285, p. 267-276, 2015.

REZA, K. M., KURNY, A., GULSHAN, F. Parameters affecting the photocatalytic degradation of dyes using $\mathrm{TiO}_{2}$ : a review. Applied Water Science, v. 7, p. 1569-1578, 2017.

ROCHA, O. R. S.; DANTAS, R. F.; NASCIMENTO JÚNIOR, W. J.; FUJIWARA, Y.; DUARTE, M. M. M. B.; SILVA, J. P. Kinetic study and modelling of cephalexin removal from aqueous solution by advanced oxidation processes through artificial neural networks. Desalination and Water Treatment, v. 92, p. 72-79, 2017.

ROSTAMI-VARTOONI, A.; NASROLLAHZADEH, M.; SALAVATI-NIASARI, M.; ATAROD, M. Photocatalytic degradation of azo dyes by titanium dioxide supported silver nanoparticles prepared by a green method using Carpobrotus acinaciformis extract. Journal of Alloys and Compounds, v. 689, p. 15-20, 2016.

ROZAS, O.; VIDAL, C.; BAEZA. C.; JARDIM, W. F.; ROSSNER, A.; MANSILLA, H. D. Organic micropollutants (OMPs) in natural waters: Oxidation by $\mathrm{UV} / \mathrm{H}_{2} \mathrm{O}_{2}$ treatment and toxicity assessment. Water Research, v. 98, p. 109118, 2016.

SALAEH, S.; JURETIC PERISIC, D.; BIOSIC, M.; KUSIC, H.; BABIC, S.; LAVRENCIC STANGAR, U.; DIONYSIOU, D. D.; LONCARIC BOZIC, A. Diclofenac removal by simulated solar assisted photocatalysis using $\mathrm{TiO}_{2}$-based zeolite catalyst; mechanisms, pathways and environmental aspects. Chemical Engineering Journal, v. 304, p. 289-302, 2016.

SANTOS, M. M. D. M.; DUARTE, M. M. M. B.; NASCIMENTO, G. E.; SOUZA, N. B. G.; ROCHA, O. R.S. Use of $\mathrm{TiO}_{2}$ photocatalyst supported on residues of polystyrene packaging and its applicability on the removal of food dyes. Environmental Technology, p. 1-14, 2018. 
SOLEYMANI, A. R.; CHAHARDOLI, R.; KAYKHAII, M. Development of $\mathrm{UV} / \mathrm{H}_{2} \mathrm{O}_{2} / \mathrm{TiO}_{2}$ - LECA hybrid process based on operating cost: Application of an effective fixed bed photo-catalytic recycled reactor. Journal of Industrial and Engineering Chemistry, v. 44, p. 90-98, 2016. 